\author{
January 2019, VOLUME 7, ISSUE 1, 92 - 112 \\ E-ISSN NO: $2289-4489$
}

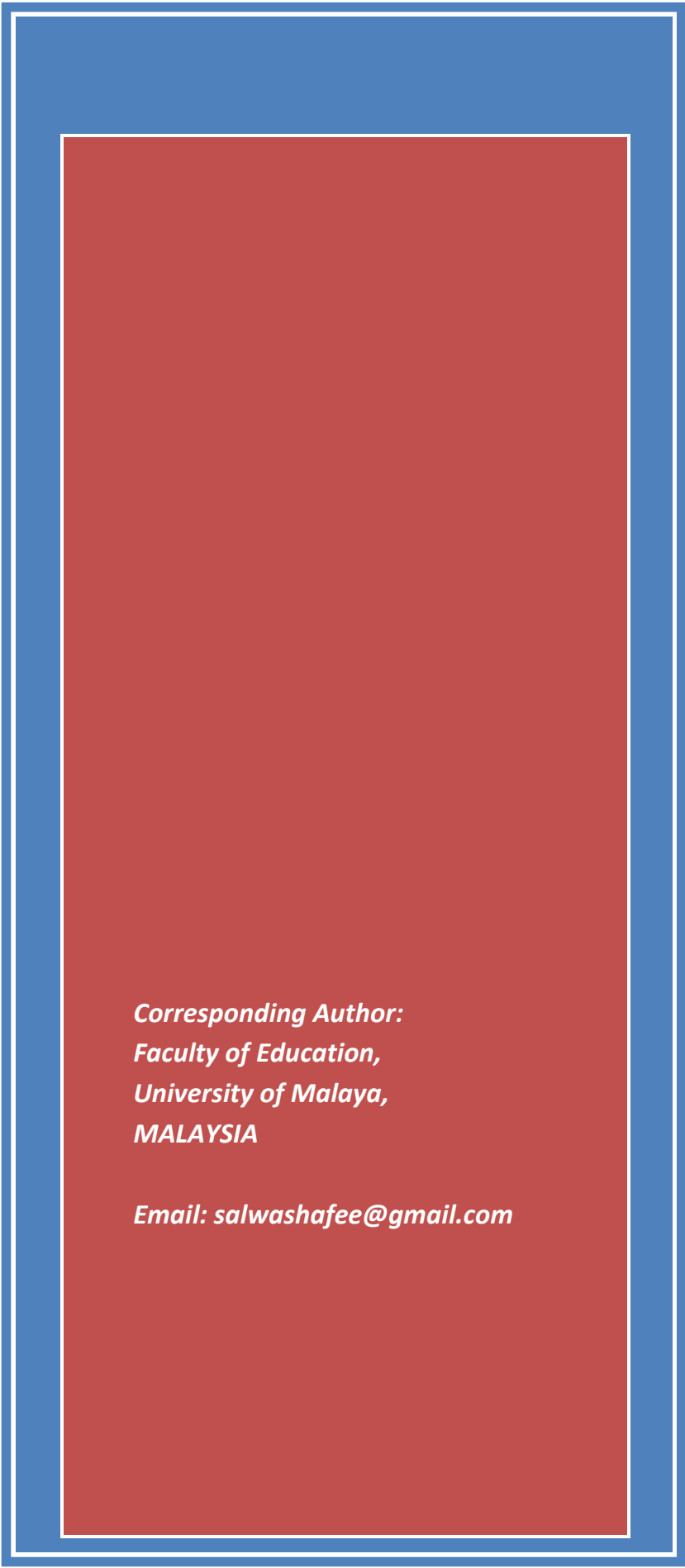

\title{
LEADERSHIP ROLE OF COACHES IN IMPROVING TEACHERS' INSTRUCTIONAL PRACTICES
}

Salwati Shafee, Simin Ghavifekr (PhD) \& Zuraidah Abdullah (PhD)

\begin{abstract}
Changing instructional practices is not an easy job. Therefore, teachers need help and support in order to create changes in their practices. In some countries like Malaysia, the support is offered through coaching. Effective coaching takes place if teachers and coaches play their effective leadership roles and equip themselves with various attributes of coaching. Subsequently, this allows instructional changes to take place. A traditional idea of leadership focus on an individual managing a hierarchical system. Therefore, it poses a significant barrier for teachers to work together and does not provide teachers with autonomy as a leader. In the practice of coaching however, teachers play the different roles of leadership. Hence, this study looks at the perception of teachers and coaches on the implementation of coaching in Malaysian schools. Moreover, it looks at a form of instructional support given to teachers in helping them to improve their classroom practices which eventually leads to increased students' learning outcome. This article specifically discusses the application of five attributes of coaching namely collaboration, support, feedback, reflect and trust. The study also looks at the leadership role of the coaches in coaching teachers to create instructional improvements. Data of this quantitative study were gathered through a set of questionnaires which was administered to 470 teachers and coaches in primary and secondary school in Selangor and Sabah. Analysis of findings were based on descriptive analysis using SPSS as well as inferential analysis using Smart PLS. The findings of the study provide and insight on the role of coaching attributes and coaching leadership in helping teachers and coaches to create changes and improvements in classroom practices which leads to increased learning outcomes. It also illustrates the significant relationship between coaching attributes and the role of leadership in the implementation of coaching in Malaysian schools.
\end{abstract}

Keywords: Coaching, Leadership, Instructional improvement, Teachers, Malaysia, Classroom Support 


\section{INTRODUCTION}

Effective teaching is vital in improving students' learning outcome. It is suggested that in order to improve teaching and learning outcomes, one must begin by focusing on improving instructional practices (Barber \& Mourshed, 2007). In fact, it is a significant measure that every school could rely on to achieves school improvement (Darling-Hammond \& Rothman, 2011). Improving instructional practices requires teachers to improve their knowledge and skills. Thus, various trainings at all levels were given to teachers through continuous professional development (Balan, Manko, \& Phillips, 2011). Teachers were to utilize the knowledge obtained from the various training given to improve their practices. However, without proper encouragement and support, the knowledge and skills gained could not be transformed into best practices which can improve learning (Richlin, 2001). This has become the reason why many professional development programs were unsuccessful and ineffective (Balan et al., 2011). This seems to contradict the objective of having teachers' professional development. Subsequently, changes that could lead to improved classroom practices and learning outcomes could not be accomplished. Therefore, teachers need some form of assistance to help transfer the knowledge and skills into new practices.

Teachers receive new knowledge and skills related to teaching and learning through professional development. Teachers were supposed to apply knowledge and skills from the various training received in the classroom, however there are instances where they failed to do so. Based on a study by Cassidy, Garret, Maxfield and Patchett (2009), it was reported that approximately only ten percent of the skills and strategies learned in the traditional professional development transformed into classroom practices. In relation to that, certain countries like Malaysia formed a group of coaches as an effort to provide support to teachers in helping them improve their instructional practices (Cornett \& Knight, 2009).

\section{Background}

Teachers need to improve instructional practices in order to improve school performance. Sergiovanni and Starratt (1979) and Knight (2007) points out that in order to improve classroom instruction, it has to begin with the teacher. Thus, under the new Malaysian Education Blueprint, (MEB, 2013-2025), teachers were to receive more support in exploiting their full potential in teaching (MOE, 2013). Teachers will receive support from coaches or also known as SISC+ (School Improvement Specialist Coach) to help them transfer the knowledge gained from trainings into practice. These coaches are required to give guidance and support to teachers through a series of coaching session which includes both group and individual one-to-one coaching sessions with the teachers (MOE, 2013). Coaching is seen as the appropriate means to help teachers improve their instructional practices. It requires teachers to work together with coaches in their attempt to and improve classroom practices and learning outcomes (Harris \& Muijs, 2005; Cornett \& Knight, 2009). Getting support from the coach would be more preferable than being supervised by their superior as empirical evidence suggested that teachers prefer seeking direct assistance from their colleagues rather than their superior (Zepeda, 2007; Glickman, Gordon, \& RossGordon, 2007).

Additionally, apart from gaining new knowledge and skills, coaching also lead to more skillful shared decision making among teachers. This is vital for self-perpetuating change in their professionalism (Bright, 2011; Joyce \& Showers, 1996; Joyce \& Showers, 1980; Knight, 2007; Marsh, McCombs \& Martorell, 2009). In other words, coaching provide room for teachers to reflect on their practices to create improvement and changes in learning outcomes. This can happen if teachers received help from their colleagues who shared similar instructional situation. 


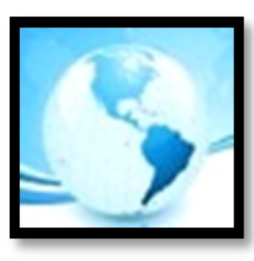

\section{Problem Statement}

In context of the $21^{\text {st }}$ century learning, teachers should be regarded as facilitators of knowledge when teaching students (Hussain \& Rahman, 2000). In Malaysia however, it is a common phenomenon to see teachers instead focus on completing the syllabus for the purpose of preparing the students for the exam (McTighe \& Brown, 2005; Caine \& Caine, 2001). Generally, lessons were carried out based on conventional teacher-centered chalk and talk method (Lim, Fatimah, \& Tan, 2002; Sharifah Maimunah, 2000). The students were passive, there was a lack of interest in learning and it does not allow room for creativity (Tan \& Arshad, 2014). This contradicts with the ideal picture of what a $21^{\text {st }}$ century classroom should look like. Subsequently, The Ministry of Education reported that only fifty percent (50\%) of the teaching and learning in schools were effective (MOE, 2013). This is one of the contributing factors to the need in improving instructional practices. The practice of coaching would help to support teachers to apply the theories learnt into practice because with the presence of a coach in the classroom, it would serve as a "mirror" for teachers to reflect on their classroom practices (Knight, 2007).

However, one of the obstacles in improving instructional practices is the evaluative nature of classroom observation. Ideally, classroom observation carried out by the administrator acts a form of guidance to teachers so they could refer to the report made by the supervisor in order to find out which area of their practices require improvement (Glickman et al., 2005; Mohd Zawawi Ali, 2002). A good and effective supervision report contains suggestions for teachers to improve classroom practices (Sullivan \& Glanz, 2000) which also encourages positive working environment among teachers. However, the school inspectorate reported that the administrator failed to produce constructive supervision which could guide teachers in improving classroom practices (MOE, 2007), instead, it is only meant to evaluate individual teacher. Therefore, some teachers view supervision as a threat due to its evaluative nature (Malm, 2009; Toll, 2009). Subsequently, teachers are reluctant to share their problems as they do not trust the supervisors (Malm, 2009; Toll, 2009).

Several studies revealed that coaching is an important means in increasing classroom practices as compared to supervision (Bush, 1984; Knight, 2007). Empirical evidence also suggests that novice teachers as well as teachers with low achievement will also benefit the most from coaching; Knight, 2007). However, the success of instructional improvement lies not on the mere effort of coaching but also on teachers' willingness to learn and reflect on their own practices (Knight, 2007). Nevertheless, coaching is as a form of support which could assist instructional improvement (Glickman, Gordon, \& Gordon, 2007). All these reflects that the role of leadership played by teachers and coaches are an important element in improving instructional practices. Additionally, the right attributes of coaching should be applied to allow room for instructional improvement to take place. Therefore, the study looked at the application of five attributes of coaching namely collaboration, support, feedback, reflect and trust in helping teachers to improve their practices. Additionally, it also looked at the role of leadership played by the coach in coaching teachers to create instructional improvements. Therefore, the study attempted to answer the following research objectives:

1) to analyse the perception and attitude of teachers and coaches in Selangor and Sabah on the practice of coaching and coach leadership;

2) to determine the relationship between coaching sub-constructs (trust, collaboration, support, feedback and reflection) and coach leadership.

Accordingly, the study sought to test the following hypotheses:

$\mathrm{H}_{1}$ : There is a significant relationship between sub-construct collaboration with coach leadership

$\mathrm{H}_{2}$ : There is a significant relationship between sub-construct support with coach leadership 


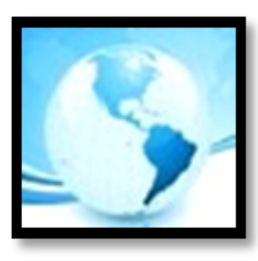

\section{MALAYSIAN ONLINE JOURNAL OF EDUCATIONAL MANAGEMENT (MOJEM)}

$\mathrm{H}_{3}$ : There is a significant relationship between sub-construct feedback with coach leadership $\mathrm{H}_{4}$ : There is a significant relationship between sub-construct reflection with coach leadership $\mathrm{H}_{5}$ : There is a significant relationship between sub-construct trust with coach leadership

\section{THEORETICAL FOUNDATION}

By increasing professional knowledge and skills, teachers could allow instructional changes to happen (Elmore, 2004; Guskey \& Yoon, 2009). However, if teachers do not receive appropriate support, the process improving practices would not take place effectively (Cornett \& Knight, 2009). In other words, teachers may be asked to improve students' learning outcome. However, if both teachers and coaches failed to exercise the right leadership roles, change within classroom practices or the learning outcomes would not take place. Therefore, leadership is an important aspect in providing support to teachers in improving their practices. By concentrating on behaviour, content knowledge, direct instruction and formative assessment, coaches and teachers can focus on improving instruction (Knight, 2007). Teachers would be able to focus on the areas for improvement by focusing on just these specific areas.

\section{Leadership in Coaching}

Plethora of research and practices has proven that leadership is an important element for sustaining school improvement (Harris \& Bennett, 2004). A traditional idea of leadership stresses on the role of individual leader to manage a hierarchical system. This condition poses a barrier for teachers to work together. Due to the demarcation of the roles and responsibilities in the system, teachers are not given the autonomy to lead (Harris \& Bennet, 2004). Coaching on the other hand encourages teachers to work together and play the different roles in leadership. For the purpose of the study, three types of leadership have been chosen, namely transformational leadership, distributed leadership as well as teacher leadership.

The first theory used for this study is transformational leadership. As opposed to the traditional system of leadership, transformational leadership does not differentiate individuals in the organization based demarcated roles. Instead, it focused at developing individuals based on their feelings, attitudes and beliefs. A school which practices transformational leadership focuses on transforming the school culture by giving a sense of freedom to teachers (Harris \& Bennet, 2004; Bush, 2011). This theory is being included in the study as coaching requires teachers to share responsibility in transforming the school culture which is aimed at improving instructional practices. Teachers will be motivated and more willing to make improvement towards classroom practices because they see a need to do so.

Transformational leadership creates changes that happen within the classroom which will eventually influence the transformation of the school (Fullan \& Knight 2011; Bush, 2011). It encourages teachers' collegiality and collaboration which then generate positive change in schools (Rosenholtz, 1989; Vangrieken, Meredith, Packer, \& Kyndt, 2017; Jones, Gardner, Robertson, \& Robert, 2013). It also allows teachers to become leaders at various time apart from having a stronger drive for improvement (Harris \& Muijs, 2005, Bush, 2011). These drives will empower teachers to create changes within their classroom within their own chosen time. Above all, transformational leader focuses on building culture which is aimed at developing school norms, values, beliefs and assumptions and support teacher professional development (Harris, 2003; Bush, 2011, 2013). Overall, transformational leadership encourages teachers to collaborate with each other apart from being reflective towards their own practices.

Distributed leadership on the other hand, focuses on collective leadership. This means that teachers work together to develop their expertise. Not only that, they were also given the responsibilities to lead and create improvement in the classroom and in the school (Harris, 2004; Bush, 2011). Thus, with the given responsibilities, teachers will be more committed towards their own practices. The role of a coach on the other hand, is to support the teachers and help them to focus on their aims and responsibilities in creating changes towards instructional practices not 


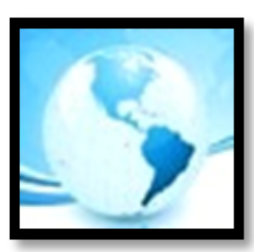

\section{MALAYSIAN ONLINE JOURNAL OF EDUCATIONAL MANAGEMENT (MOJEM)}

only at individual level but also in creating school culture. Overall, the theory of distributed leadership stresses on the shared responsibility between members of the organization and the leader (Goleman, 2002). It is about maximizing skills and abilities within the organization in order to achieve common goals (Harris, 2004). Various studies have proven that distributed leadership brought about positive impact on school improvement especially on students' achievement (Harris, 2004; Bush, 2011). This implies that interaction and interdependency among multiple leaders in an organization could lead to significant results.

Another theory used in this study is teacher leadership. Teacher leadership focuses on peer control with the emphasis on teacher collegiality. Mutual trust and support are similarly important for effectiveness in teacher leadership. Teachers would be more open to share their problems or seek help from the coach as coaches are also teachers. Once trust towards the coach is established, they will be more open to receive feedback and support from the coach. With teacher leadership, meaningful changes in instructional practices would take place within the school when everyone work together collectively (Harris, 2003; Bush, 2011; Killion et al., 2016). Various studies have been done in the last decades to show how teacher leadership contributes towards school improvement (Little, 2003; Killion et al., 2016). As such, teachers and coaches are regarded as change agents within the organization. Therefore, it is important that teachers and coaches work together as one so they could provide support to the other.

All the three leadership theories are significant important in ensuring the effectiveness of coaching. Therefore, both the coach and teachers should play the various roles interchangeably during coaching sessions. Distributed leadership allows the roles and responsibilities being shared by the teachers and not the sole responsibility of the principle. Teacher leadership on the other hand creates high commitment among teachers in improving instructional practices. Whereas transformational leadership, allows collaboration among teachers and coaches in transforming the working culture of the school.

\section{Coaching}

With regards to the theory of coaching, there are various types of coaching being discussed in the literature namely collegial coaching, peer coaching, executive coaching and several others. These theories are distinct from one another; however, it has a common goal which is to improve their practices and outcomes. Various models of coaching have been developed over the past decades. One of the contemporary coaching models is Instructional Coaching which was developed by Knight (2004). The theory is based on the theoretical framework of partnership approach (Knight, 2003). Some of the attributes of instructional coaching are overcoming fear, collaboration, modeling, observation and providing feedback, support as well as building emotional connection (Knight, 2007).

One of the elements of coaching is collaboration. As participants of a learning process and equal partner, teachers need to feel that their experience and opinions are appreciated, valued and respected. They also need to be actively involved in the learning process that helps them to grow and change (Fullan \& Knight, 2011). Collaboration focuses on the quality of ongoing relationship between coach and the teacher. It is the most noted characteristics of coaching (Knight, 2011). Instead of being told what to do, the ideal context of instructional coaching is teachers engage as equal partner in their professional development activities (Thomas, Bell, Spelman, \& Briody, 2015; Knight, 2011). Teachers and coaches work together to discuss on the problems faced by teachers pertaining to their classroom practices.

Trust is very important in order for coaching to be effective. With the presence of trust, conflicts and disagreement are easier to be controlled. When teachers developed trust among each other, it is easier for them to share problems and views pertaining to their professional practices. Conflicts however, need not necessarily be perceived as negative. In fact, it could help to stretch people's ideas and collaborative learning opportunities (Attard, 2012; Vause; 2009). With the presence of conflicts, teachers learn to admit weaknesses in their practices while at the same time trying to break free from their comfort zone (Brodie, 2014). Collaboration between coach 


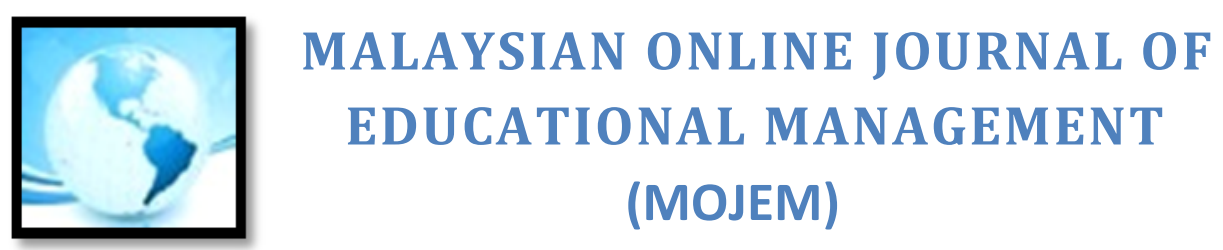

and teacher would lead to reflective decision making that would allow changes in instructional practices to take place.

Coaching also offers teachers a form of support. Coaching has also been used as a form of professional development strategy for teachers to increase their competence and most of the research done on instructional coaching has mostly been exploratory (Elsenberg, 2016; Thomas et al., 2015). It has been empirically proven that coaching has been able to increase the implementation or skill transfer (Cornett \& Knight, 2009) which also closely related to increasing teacher professional growth (Elsenberg, 2016). Through instructional coaching, it has enabled teachers to increase students' achievement by learning and implementing new ideas and practices in the classroom (Cornett \& Knight, 2009). Here, armed with proper knowledge and skills, instructional coaching provides a form of support to teachers to implement best instructional practice.

Coaching also allows teachers to develop their expertise in instructional practices by receiving feedback from the coach which in turn, help them to reflect on their own practices. Improving practices is a long process which involves a lot of effort. Therefore, the coach must be knowledgeable about instruction (David, 2007) so that during classroom observation, the coach acts as a mirror to the teacher. Teachers can reflect on their own practices during post-observation conference or during feedback session (Blasé \& Blasé, 1999; Knight, 2007). It is a form of support that helps to bind many aspects related to instructional improvement.

The Conceptual Framework for the study is derived from three main theories i.e. Leadership Theory (Bush, 2011); Coaching Theory (Knight, 2007) as well as Instructional Improvement Theories (Balan et al., 2011). Figure 1 illustrates the underpinning theories used in this study and shows how leadership in coaching could affect instructional improvement and vice versa.

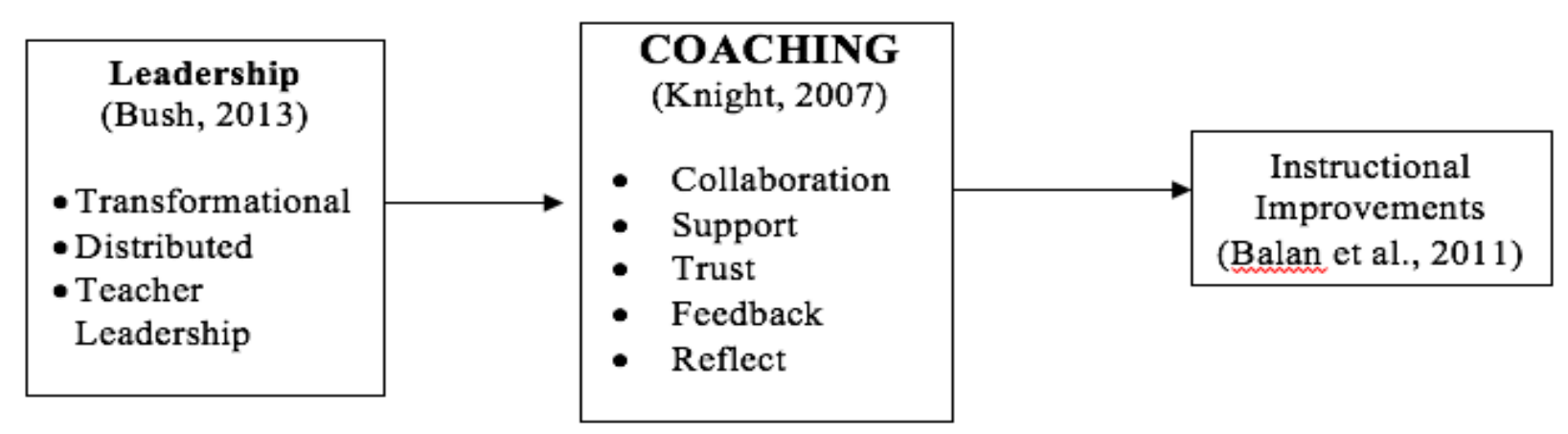

Figure 1. Conceptual Framework of the Study

\section{METHODOLOGY}

The study was conducted based on quantitative research design. Therefore, data in this study were collected using a set of questionnaire. This is in line with the purpose of the study which sought to describe the implementation of coaching in Malaysian schools. This quantitative study involved statistical and inferential analysis based on numerical evidence aimed at exploring relationship between variables (Burns \& Grove, 2009) involved in the implementation of coaching in Malaysian schools 


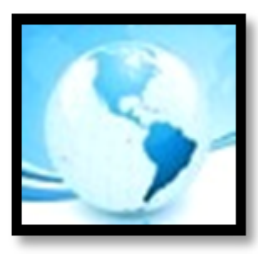

MALAYSIAN ONLINE JOURNAL OF

EDUCATIONAL MANAGEMENT

(MOJEM)

Sampling

For the purpose of this research, 393 teachers and 77 coaches (SSC+) from Selangor and Sabah were randomly chosen as samples for the pilot study, which brings to a total of 470 respondents. The teachers and coaches were selected based on their involvement in the implementation of coaching in schools.

\section{Instrumentation}

For the purpose of data collection, a total 1500 questionnaire were distributed and only 470 questionnaires were completed and returned. The instrument was adapted from four different instruments from previous research (Eismin, 2015; Frye, Robins, \& Ed, 2015; Parman, 2015; Reed, 2015) to measure various elements and variables related to the study in the local Malaysian school context. All the items were based on 5 point Likert Scale with 1 being Strongly Disagree and 5 being strongly Agree. The instrument consisted of 24 items on coaching construct and 14 items on leadership construct. The instrument has been validated by four panel of experts in the field of coaching for content and construct validity. The instrument has also undergone a pilot study for the purpose of testing reliability with the value Cronbach's alpha .937 for construct coaching and .882 for construct leadership.

\section{Data Collection Procedure}

Prior to data collection, permission from the Education Policy Planning and Research Division (EPRD) were obtained. Subsequently, a letter asking for permission to conduct a research was also sent to the State Education Department. Once permission was granted, a letter asking for permission was also sent to 10 District Education departments in Selangor and 24 District Education departments in Sabah. Next, questionnaires for the study were delivered to all the SISC in all the District Education Department involved. The selection of teacher-respondents were done at random by each SISC+ based on the list of teachers assigned to them. Data collection procedures for the study were carried out in from mid-February till end of June.

\section{Data Analysis}

Data collected for the study were analysed using descriptive and inferential analysis methods. Statistical Package for the Social Sciences (SPSS version 23) was used for statistical analysis (Creswell, 2013; Hair, Hult, Ringle \& Sarstedt, 2014; Ramayah, Cheah, Chuah, Ting, \& Mumtaz, 2018) related to the implementation of coaching based on mean score and standard deviation. In addition, Partial Least Square (PLS) Structural Equation Modelling (SEM) was used for inferential analysis in determining the relationship between variables (Hair, 2016; Ramayah et al., 2018).

Descriptive statistics using means and standard deviation was used to answer the first objective of the study which is aimed at analysing teachers' and coaches' perception on the implementation of coaching based five sub constructs namely collaboration, feedback, reflect, support as well as trust. On the other hand, PLS Structural Equation Modelling was applied for the purpose of analysing the relationship between constructs coaching and leadership. Interpretation of mean score at each level of this variable was obtained by finding the highest and lowest scores difference and interpreted based on interpretation table modified from Nunally and Bernstein (1994). The interpretation of the level of mean value is as follows, mean value of 1.00 to 2.00 as very low, mean value of 2.01 to 3.00 as moderately low, mean value of 3.01 to 4.00 as moderately high and mean value of 400 to 5.00 as high. 


\section{FINDINGS}

Sub-Constructs of Coaching: Collaboration, Feedback, Reflect, Support, Trust and Leadership

Data analysis based on the perception of teachers and coaches was carried out to see if there is any difference between teachers' and coaches' perception on the practice of coaching based on sub construct collaboration, feedback, reflect, support and trust which existed during coaching as shown in the table below. Table 1 illustrates means values and standard Deviation of teachers and coaches' perception on sub construct Collaboration based on Roles.

Table 1

Mean Values and Standard Deviation sub construct Collaboration based on Role

\section{Collaboration}

\begin{tabular}{|c|c|c|c|c|c|c|}
\hline & Items & Role & $\mathbf{N}$ & Mean & $\begin{array}{l}\text { Std. } \\
\text { Deviation }\end{array}$ & Level \\
\hline \multirow[t]{2}{*}{1} & The coach observes and identifies areas of strength & Coach & 77 & 4.68 & .549 & High \\
\hline & & Teacher & 393 & 4.26 & .664 & High \\
\hline \multirow[t]{2}{*}{2} & The coach and teacher provide tutoring to & Coach & 77 & 2.83 & 1.044 & Low \\
\hline & & Teacher & 393 & 3.68 & .895 & Moderate \\
\hline \multirow[t]{2}{*}{3} & $\begin{array}{l}\text { The coach and teacher plan and present a shared } \\
\text { lesson }\end{array}$ & Coach & 77 & 3.97 & .778 & Moderate \\
\hline & & Teacher & 393 & 4.04 & .850 & High \\
\hline \multirow[t]{2}{*}{4} & $\begin{array}{l}\text { The coach model lessons or particular instructional } \\
\text { techniques in the classroom }\end{array}$ & Coach & 77 & 4.16 & .812 & High \\
\hline & & Teacher & 393 & 4.01 & .934 & High \\
\hline \multirow[t]{2}{*}{5} & The coach helps teacher to administer assessment & Coach & 77 & 3.58 & 1.018 & Moderate \\
\hline & & Teacher & 393 & 3.88 & .893 & Moderate \\
\hline \multirow[t]{2}{*}{6} & $\begin{array}{l}\text { The coach works collaboratively with teachers at all } \\
\text { levels }\end{array}$ & Coach & 77 & 4.36 & .626 & High \\
\hline & & Teacher & 393 & 4.10 & .830 & High \\
\hline \multirow[t]{2}{*}{7} & Coaches work directly with teachers & Coach & 77 & 4.53 & .620 & High \\
\hline & & Teacher & 393 & 4.23 & .759 & High \\
\hline \multirow[t]{2}{*}{8} & The coach and teachers work together to identify & Coach & 77 & 4.31 & .712 & High \\
\hline & & Teacher & 393 & 4.09 & .789 & High \\
\hline
\end{tabular}


Based on the results in Table 1, coaches' perception on item No. 1 was the highest with mean value 4.68 as compared to teacher mean value 4.26 with. However, for item No. 2, coach perception has the lowest mean value with 2.83 when compared to teachers with mean value 3.68. As for teachers, the item with the highest mean value is item No. 1 and item with the lowest mean is item No. 8. This shows that both the coach and teachers agree that collaboration between teachers and coaches were the highest in item No. 1 when the coach observes and identifies areas of strength and needs as it relates to teaching. However, coach thinks that collaboration is the lowest when teachers and coaches provide tutoring to individual students. It also reflects that such collaboration is the least practiced. On the other hand, teachers think that collaboration least existed when teachers and coaches work together to identify professional development activities based on students' academic needs. Overall, teachers and coaches perceived that the implementation of collaboration in coaching were high although there were certain items which were moderately high.

Table 2 illustrates means values and standard deviation of teachers and coaches' perception on sub constructs feedback and reflect based on Roles.

Table 2

Mean values on Standard Deviation on Sub-Constructs Feedback and Reflect based on Roles

\begin{tabular}{|c|c|c|c|c|c|c|}
\hline & Items & Role & $\mathbf{N}$ & Mean & $\begin{array}{l}\text { Std. } \\
\text { Deviation }\end{array}$ & Level \\
\hline \multicolumn{7}{|c|}{ Feedback } \\
\hline \multirow[t]{2}{*}{9} & Coach provides meaningful feedback regarding teacher & Coach & 77 & 4.62 & .586 & High \\
\hline & & Teacher & 393 & 4.25 & .726 & High \\
\hline \multirow[t]{2}{*}{10} & $\begin{array}{l}\text { Coach feedback will help teachers improve students' } \\
\text { understanding of the concept taught }\end{array}$ & Coach & 77 & 4.51 & .620 & High \\
\hline & & Teacher & 393 & 4.22 & .755 & High \\
\hline \multirow[t]{3}{*}{11} & Self-reflection on teacher teaching practice is valuable & Coach & 77 & 4.66 & .528 & High \\
\hline & & Teacher & 393 & 4.32 & .716 & High \\
\hline & Reflective & & & & & \\
\hline \multirow[t]{2}{*}{12} & The coach and teacher were reflective about students' & Coach & 77 & 4.38 & .670 & High \\
\hline & & Teacher & 393 & 4.23 & .738 & High \\
\hline \multirow[t]{2}{*}{13} & $\begin{array}{l}\text { The coach and teacher were reflective about the teaching } \\
\text { practices }\end{array}$ & Coach & 77 & 4.45 & .680 & High \\
\hline & & Teacher & 393 & 4.29 & .702 & High \\
\hline \multirow[t]{2}{*}{14} & $\begin{array}{l}\text { Teacher felt comfortable with the coach reflection on } \\
\text { his/her teaching practice }\end{array}$ & Coach & 77 & 4.05 & .759 & High \\
\hline & & Teacher & 393 & 4.11 & .755 & High \\
\hline \multirow[t]{2}{*}{15} & $\begin{array}{l}\text { The coach assists teachers in being reflective about their } \\
\text { own professional learning }\end{array}$ & Coach & 77 & 4.38 & .563 & High \\
\hline & & Teacher & 393 & 4.11 & .766 & High \\
\hline
\end{tabular}




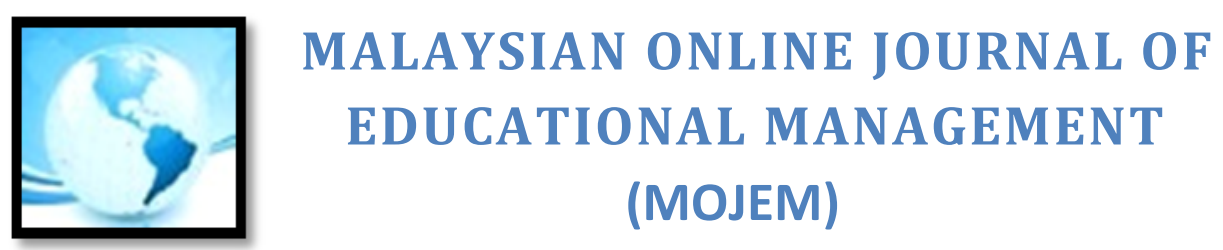

Based on the result in Table 2, for sub construct feedback, both teachers and coaches strongly agree that feedback is an important element existed in the practice of coaching with the mean value between $4.22(S D=.755)$ to $4.66(S D=.528)$. This suggests the uniformity of opinion between teachers and coaches on feedback sub construct. However, coaches have a slightly higher opinion on all the items of feedback. Both coach and teacher think that the item feedback is highly practiced when teachers carried out self-reflection as it is valuable.

Similarly, for Reflective sub-construct, there is only minimal difference in the mean values between teachers and coaches in all the items also show that teachers and coaches agrees that reflective element is being practiced in coaching. The mean values are between 4.11 (SD= .755) to 4.38 (SD.670). However, between the two groups, coaches have a slightly higher agreement in most of the items as compared to teachers. Both teachers and coaches agreed that reflect were the highest when the coach and teachers were reflective about teaching practices and both agrees that item 14 has the lowest mean in sub construct reflect as they have lower confidence that teachers felt comfortable with the reflection on teacher teaching practices. Overall, coaches seem to be positive towards the implementation of coaching, as reflected in their opinions and views which is most of the time higher than teachers. Overall, teachers and coaches perceive that the implementation of feedback and reflect during coaching were high. Nevertheless, coaches tend to have slightly higher perception as compared to teachers

Table 3 illustrates means values and standard Deviation of teachers and coaches' perception of sub constructs support and trust based on Roles.

Table 3

Mean Values and Standard Deviation on Sub Construct Support and Trust based on Roles

\begin{tabular}{|c|c|c|c|c|c|c|}
\hline & Item & Role & $\mathbf{N}$ & Mean & SD & Level \\
\hline \multicolumn{7}{|c|}{ Support } \\
\hline \multirow[t]{2}{*}{16} & $\begin{array}{l}\text { The coach supports teachers in their reflection and analysis of their } \\
\text { practices }\end{array}$ & Coach & 77 & 4.49 & .599 & High \\
\hline & & Teacher & 393 & 4.15 & .770 & High \\
\hline \multirow[t]{2}{*}{17} & The coach supports teachers' implementation of best practices & Coach & 77 & 4.62 & .563 & High \\
\hline & & Teacher & 393 & 4.31 & .717 & High \\
\hline \multirow[t]{2}{*}{18} & $\begin{array}{l}\text { The coach should communicate and emphasize their role as a } \\
\text { support rather than an evaluator }\end{array}$ & Coach & 77 & 4.73 & .529 & High \\
\hline & & Teacher & 393 & 4.30 & .705 & High \\
\hline \multirow[t]{3}{*}{19} & $\begin{array}{l}\text { Coaches provide modeling, practice and feedback of instructional } \\
\text { strategies to teachers }\end{array}$ & Coach & 77 & 4.30 & .745 & High \\
\hline & & Teacher & 393 & 4.05 & .851 & High \\
\hline & Trust & & & & & \\
\hline \multirow[t]{2}{*}{20} & It is important that teacher trusts the coach & Coach & 77 & 4.74 & .497 & High \\
\hline & & Teacher & 393 & 4.27 & .772 & High \\
\hline \multirow[t]{2}{*}{21} & Teacher felt comfortable communicating with the coach & Coach & 77 & 4.42 & .593 & High \\
\hline & & Teacher & 393 & 4.26 & .733 & High \\
\hline \multirow[t]{2}{*}{22} & $\begin{array}{l}\text { Teachers felt coach respects their opinion, understands the } \\
\text { situation, and the challenges faced }\end{array}$ & Coach & 77 & 4.44 & .596 & High \\
\hline & & Teacher & 393 & 4.23 & .780 & High \\
\hline
\end{tabular}




$\begin{array}{lllll}\text { Coach } & 77 & 4.38 & .608 & \text { High } \\ \text { Teacher } & 393 & 4.36 & .690 & \text { High } \\ \text { Coach } & 77 & 4.64 & .583 & \text { High } \\ \text { Teacher } & 393 & 4.24 & .756 & \text { High }\end{array}$

Table 3 on the other hand illustrates teachers' and coaches' perceptions on sub-constructs support and trust based on roles. The results show that for sub construct support coaches have a higher mean value between 4.30 to 4.62 as compared to teachers with mean value between 4.15 to 4.31 . Again, the results showed that coaches seem to have a more positive view on sub construct support. Nevertheless, teachers and coaches strongly agree that support existed in the practice of coaching. For coach, item 18 has the highest means which indicates that coach believe that they should communicate their role as support rather than evaluator. Teachers also think the same but item No. 17 has a higher mean for teachers which means that they also think that support is more prevalent when coaches support teachers' implementation of best practices.

For sub construct trust, the coaches' views have a higher mean value between 4.38 to 4.74 as compared to teachers with mean values between 4.23 to 4.36 . However, both groups strongly agree that trust existed during coaching. Coaches think that it is important that teacher trust the coach (Item No. 20) whereas for teachers they chose item No. 23 to show that trust highly existed during coaching when teachers value coach's input. Overall, teachers and coaches perceived that the implementation of support and trust during coaching were high. Nevertheless, coaches tend to have slightly higher perception on both constructs as compared to teachers.

Table 4 illustrates means values and standard deviation of teachers and coaches' perception on construct Leadership based on Roles.

Table 4

Mean and Standard Deviation for Construct Leadership Based on Roles

\begin{tabular}{|c|c|c|c|c|c|c|}
\hline & Item & Role & $\mathbf{N}$ & Mean & SD & Level \\
\hline \multirow[t]{2}{*}{48} & $\begin{array}{l}\text { Help teachers analyse the content, strategy, and } \\
\text { quality of their lessons }\end{array}$ & Coach & 77 & 4.29 & .704 & High \\
\hline & & Teacher & 393 & 4.02 & .787 & High \\
\hline \multirow[t]{2}{*}{49} & $\begin{array}{l}\text { Model lessons or particular instructional techniques in } \\
\text { the classroom }\end{array}$ & Coach & 77 & 4.22 & .661 & High \\
\hline & & Teacher & 393 & 3.94 & .911 & Moderate \\
\hline \multirow[t]{2}{*}{50} & $\begin{array}{l}\text { Meet with other coaches or curriculum specialists for } \\
\text { planning purposes }\end{array}$ & Coach & 77 & 4.18 & .739 & High \\
\hline & & Teacher & 393 & 3.81 & .867 & Moderate \\
\hline \multirow[t]{2}{*}{51} & $\begin{array}{l}\text { Collaborate with teachers to improve students' } \\
\text { learning }\end{array}$ & Coach & 77 & 4.42 & .570 & High \\
\hline & & Teacher & 393 & 4.15 & .761 & High \\
\hline \multirow[t]{2}{*}{52} & Facilitate department level planning & Coach & 77 & 3.81 & .974 & Moderate \\
\hline & & Teacher & 393 & 3.77 & .888 & Moderate \\
\hline \multirow[t]{2}{*}{53} & Deliver school-wide professional development & Coach & 77 & 4.05 & .902 & Moderate \\
\hline & & Teacher & 393 & 3.96 & .798 & Moderate \\
\hline \multirow[t]{2}{*}{54} & Support the decision made by teachers & Coach & 77 & 4.21 & .675 & High \\
\hline & & Teacher & 393 & 4.01 & .746 & High \\
\hline \multirow[t]{2}{*}{55} & Observe classroom teaching & Coach & 77 & 4.51 & .620 & High \\
\hline & & Teacher & 393 & 4.20 & .740 & High \\
\hline 56 & Engage in pre and post conferencing with teachers & Coach & 77 & 4.49 & .700 & High \\
\hline
\end{tabular}




\begin{tabular}{|c|c|c|c|c|c|c|}
\hline & & Teacher & 393 & 4.15 & .819 & High \\
\hline \multirow[t]{2}{*}{57} & $\begin{array}{l}\text { Help teachers use assessment data to improve } \\
\text { instruction }\end{array}$ & Coach & 77 & 4.22 & .681 & High \\
\hline & & Teacher & 393 & 3.88 & .884 & Moderate \\
\hline \multirow[t]{2}{*}{58} & Help teachers plan lessons together & Coach & 77 & 4.08 & .739 & High \\
\hline & & Teacher & 393 & 3.95 & .870 & Moderate \\
\hline \multirow[t]{2}{*}{59} & Working with teachers towards the same objectives & Coach & 77 & 4.35 & .664 & High \\
\hline & & Teacher & 393 & 4.09 & .795 & High \\
\hline \multirow[t]{2}{*}{60} & $\begin{array}{l}\text { Allow teachers to make their own decision pertaining } \\
\text { to improving practices }\end{array}$ & Coach & 77 & 4.40 & .591 & High \\
\hline & & Teacher & 393 & 4.12 & .736 & High \\
\hline \multirow[t]{2}{*}{61} & Help teachers implement a particular curriculum & Coach & 77 & 4.10 & .788 & High \\
\hline & & Teacher & 393 & 3.84 & .838 & Moderate \\
\hline
\end{tabular}

Based on Table 4, the mean values for coach are between 3.77 to 4.51 while mean value for teachers are between 3.81 to 4.20 . It shows that coaches have higher views and opinions regarding their leadership in coaching while teachers tend to have lower opinion on coaches' leadership. Both coaches and teachers agree the most on the role of coach in observing classroom teaching as compared to other roles. Both coaches and teachers agreed the least on coach's role in facilitating department level planning. This indicates that both teachers and coaches have similar views on the coach leadership. Overall, teachers and coaches perceived that coach leadership during coaching were mostly high although several items were moderately high. Nevertheless, coaches tend to have slightly higher perception on coach leadership as compared to teachers.

\section{Relationship Between Coaching Sub-Constructs and Coach Leadership}

In order to assess if there is a significant relationship between coaching sub-constructs (trust, collaboration, support, and reflection) with coach leadership, five hypotheses were developed:

Hypothesis:

$\mathrm{H}_{1}$ : There is a significant relationship between sub-construct collaboration with coach leadership

$\mathrm{H}_{2}$ : There is a significant relationship between sub-construct support with coach leadership

$\mathrm{H}_{3}$ : There is a significant relationship between sub-construct feedback with coach leadership

$\mathrm{H}_{4}$ : There is a significant relationship between sub-construct reflection with coach leadership

$\mathrm{H}_{5}$ : There is a significant relationship between sub-construct trust with coach leadership

For the purpose of hypothesis testing, the value of R2 and Beta ( $\beta$ ) were assessed. The value of the relationship strength between the constructs is represented by the Beta $(\beta)$ value while the value of the contributions of all the variables is seen through $R$ square (R2) values. Beta ( $\beta$ ) value explaining path coefficients values (in between +1 to 1 ) are used for analysing of the strength of the hypothesized relationships. The path coefficients values close to +1 represent strong positive relationship whereas a value near 0 represents weak relationship.

Figure 1 and Table 5 illustrates the result of the analysis on the relationship between coaching constructs (Collaboration, Feedback, Reflect, support and Trust) and leadership construct. 


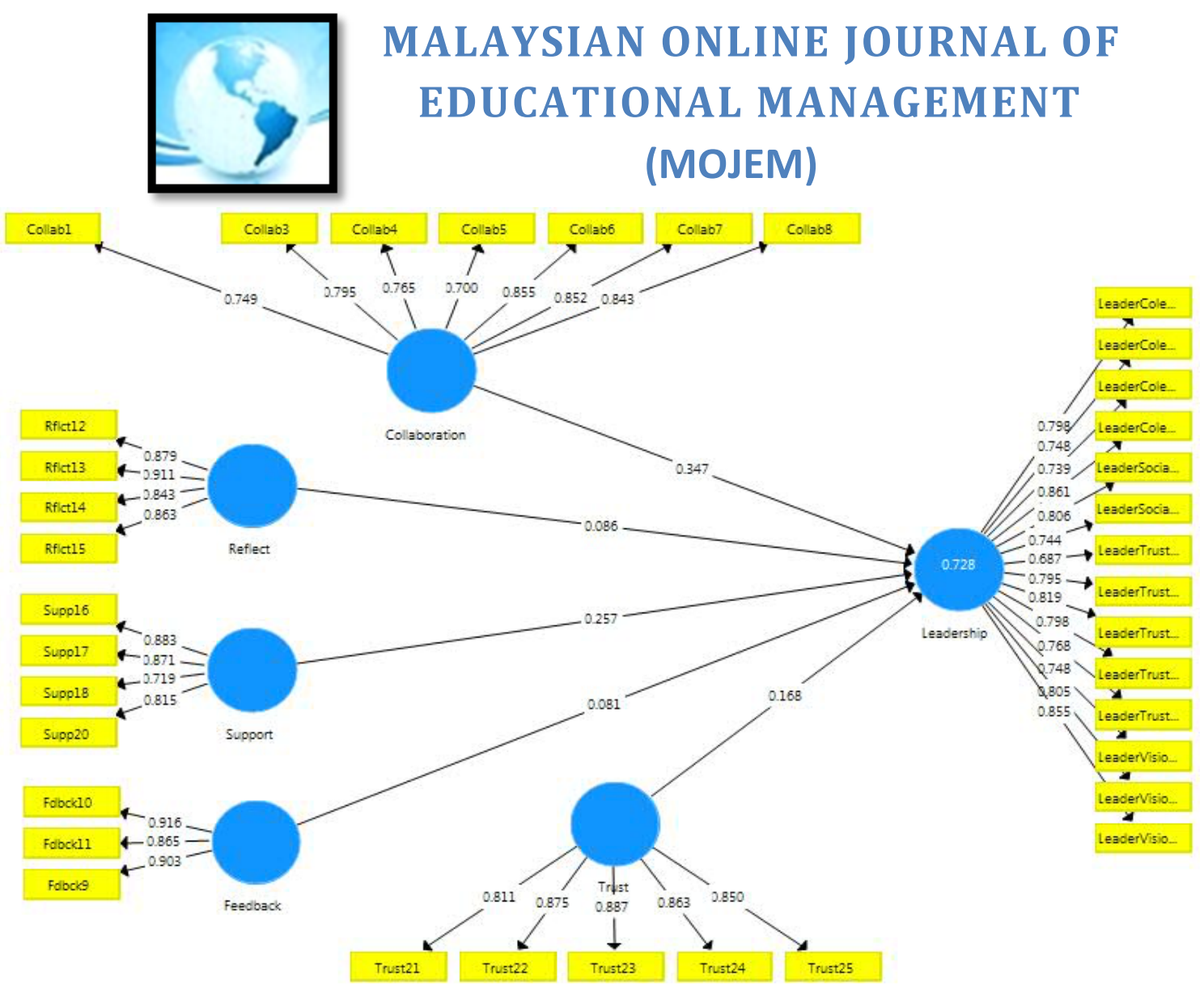

Figure 2. Relationship between Coaching Construct (Collaboration, Feedback, Reflect, support and Trust) and Leadership Construct

The strength of a relationship between variables is represented by the t-value and the level of significance. The result of the structural model (Figure 1) and the assessment in Table 5 shows that, the most significant relationship with coaching sub-construct and leadership construct is collaboration with t-statistics greater than 1.96 ( $\beta=0.347$, $t=6.977, p=0.00)$ followed by support $(\beta=0.257, t=4.249, p=0.00)$, trust $0.168, t=3.421, p=0.001)$., reflect $(\beta=0.086, t=1.592, p=0.112)$. and feedback $(\beta=0.081, t=1.419, p=0.156)$.

Table 5 illustrates the result of the analysis on the relationship between coaching constructs (Collaboration, Feedback, Reflect, support and Trust) and leadership construct.

Table 5

T-statistics, standardized regression weight, (B) and $R 2$ of path coefficients of coaching constructs towards Leadership.

\begin{tabular}{llrrrrrrr}
\hline & Relationship & $\begin{array}{l}\text { Std } \\
\text { Beta }\end{array}$ & Std. Dev & T Statistics & $\begin{array}{l}\text { P } \\
\text { Values }\end{array}$ & R2 & f2 & Result \\
\hline HI & $\begin{array}{l}\text { Collaboration }>> \\
\text { Leadership }\end{array}$ & 0.347 & 0.050 & 6.977 & 0.000 & 0.728 & 0.140 & Accepted \\
H2 & Feedback -> Leadership & 0.081 & 0.057 & 1.419 & 0.156 & 0.006 & Not Accepted \\
H3 & Reflect $\rightarrow$ Leadership & 0.086 & 0.054 & 1.592 & 0.112 & 0.006 & Not Accepted \\
H4 & Support -> Leadership & 0.257 & 0.061 & 4.249 & 0.000 & 0.049 & Accepted \\
H5 & Trust $\rightarrow$ Leadership & 0.168 & 0.049 & 3.421 & 0.001 & 0.038 & Accepted \\
\hline
\end{tabular}

*Significant at $\mathrm{p}<.05 ; * *$ Significant at $\mathrm{p}<.01 ; * * *$ Significant at $\mathrm{p}<.001$ 


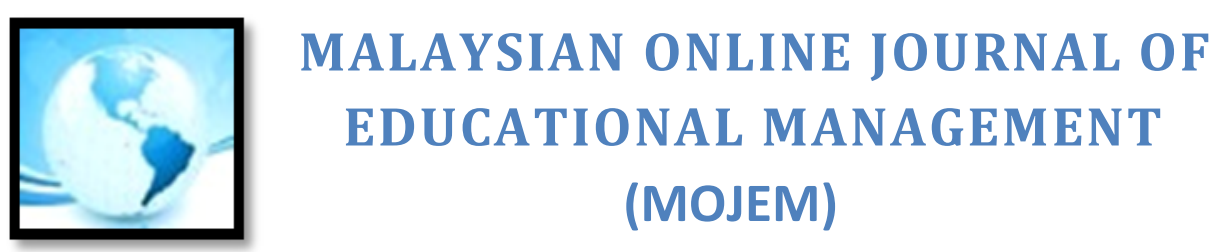

It can be interpreted that collaboration between the coach and teachers is vital in providing the support needed by teachers to help improve their practices. As leaders, coaches need to provide instructional support to teachers. In terms of support, teacher values constructive feedback provided by the coach as it would help teachers to reflect freely on their own practices. Trust towards the coach needs to be established before teachers could reflect on their own practices and values the feedback received from the coaches. On the other hand, although coaching is about reflecting on practices and feedback, the findings shows that the effect of both reflect and feedback on the current practice of coaching is low. This suggests that both aspects of coaching practice needs to be more focused and improved. After all, coaching is about being able to reflect on teacher's practices and receiving appropriate feedback.

The R 2 value gives us the combined effects of independent variables on the dependent variable i.e. it represents the amount of variance in the endogenous constructs explained by all of the exogenous constructs linked to it (Hair et al., 2014). The R2 value ranges ( 0 to 1 ) and value near to 1 indicates high predictive accuracy. According to Chin (1998), the value of R2 = 0.67 is substantial, 0.33 is moderate, 0.19 is weak. Based on the findings of the study, the R2 value of Leadership (dependent variable) for this study is 0.728 . In could be interpreted that the effect of coaching sub-constructs (collaboration, feedback, reflect, support and trust) caused $72.8 \%$ substantial effect on coach leadership.

In addition, the p-value informs the reader if an effect exists, but does not reveal the size of the effect Thus, another aspect to look at is size effects (f2). The impact of variables on other variables can be seen with effect size (effect size F2). The effect of size can be measured based on 3 values i.e. $0.02=$ small effect, $0.15=$ medium effect and $0.35=$ large effect (Chin, 1998). Based on the findings, it is observed that the effect size of Collaboration-Lead (0.140), Support-Lead (0.049), Trust-Lead (0.038), Feedback-Lead (0.006) and Reflect-Lead (0.006) have small effect size. It can be interpreted as although coaching sub-construct may affect coach leadership, yet the effect is small.

Therefore, based on the analysis of Beta value, R2 value as well as $\mathrm{f} 2$ effect, it is concluded that hypothesis $\mathrm{H} 1$, $\mathrm{H} 4$ and $\mathrm{H} 5$ are statistically significant with t-statistics greater than 1.96 , however $\mathrm{H} 2$ and $\mathrm{H} 3$ are not statistically significant with t-statistics less than 1.96 .

\section{DISCUSSION}

Instructional coaching is a process of providing support to teachers to create instructional changes. In relation to that, coaching has been newly implemented in the Malaysian educational system. Nevertheless, there are various discussions on barriers and challenges in implementing educational change or reform. These challenges include teacher resistance towards coaching due to various factors. Resistance is a form of teachers communicating their concerns regarding particular change especially when their opinions and experience are not being heard or valued (Thornburg \& Mungai, 2011). Therefore, it would influence teachers' attitude and views over the newly implemented curriculum. However, these views and attitude would change over time especially when they starting to see positive changes. The results of the study showed that teachers and coaches have similar views and perception regarding the elements of coaching. However, in general, coaches' views tend to be slightly higher than that of teachers. The following section will discuss on the findings of the study based on each particular construct.

\section{Providing Support}

Based on the results of data analysis, it is clear that coaching is about providing support to teachers. Both teachers and coaches agree on that providing support is being highly practiced among teachers and coaches. However, coaches tend to have higher views and perception towards coaching. They tend to have more positive attitude towards the implementation of coaching as a form of support to for teachers. Perhaps, it is because coaching is a newly implemented curriculum which meant at bringing about changes related to classroom practices. Therefore, 


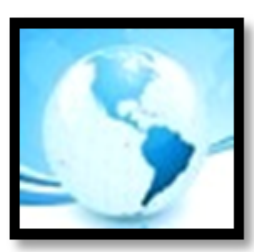

\section{MALAYSIAN ONLINE JOURNAL OF EDUCATIONAL MANAGEMENT (MOJEM)}

changes within teacher practices take time. This is also due to the fact that educational change is socially complex and requires careful planning and coordinating a multilevel social process which involve various individuals (Fullan, 2006). Consequently, significant change, which largely depends on how teachers and coaches interact with one another at providing technical help and support, would eventually bring about changes in beliefs and practices and vice versa.

In providing support, the coach needs to use the appropriate skills and knowledge such as knowledge in content, curriculum, pedagogy and coaching resources (Brady, 2007). Being able to practice the right questioning technique and allow opportunity for teacher to reflect on their practices is also a form of support (Feger et al., 2004). In addition, being open minded and knowing how to respect others' opinions, enthusiasm, optimism, confidence and decision is similarly important (Ingersoll, 2007). These are some aspects of coaching that a coach should exercise in providing support to help teachers improve their instructional practices. In short, the coach needs to exercise the right elements of coaching in helping teachers improve classroom practices.

\section{Collaboration}

The findings of the study also revealed that collaboration among teachers and coaches through coaching is highly practiced. In fact, the form of collaboration which took place through coaching have changed teachers' perspective towards best practices. (Hall, 2005; Knight, 2006). Collaboration enables gaining of new skills and information which are related to their instructional needs. Through collaboration, materializing their goals seemed even more possible with the help received from coach (Knight, 2006). Working together with others could be difficult to certain individuals, however, collaboration is key in building teacher and coach relationship (Jorissen et al., 2008; Regge \& Soine, 2008; Russo, 2004). When teachers collaborate, they show strong ownership and involvement in improving instruction (Harris \& Muijs, 2005). This implies that in creating changes within the classroom and the school as a whole, collaboration among teachers and coaches are vital.

Collaboration among teachers and coaches allow discussion and conversation to take place in order to generate change and growth as reflected in the analysis of construct collaboration. Collaboration help coaches and teachers identify areas of strength and needs as it relates to teaching. Apart from focusing on developing individual needs, the conversation between coach and teachers would be easier to take place if the goal of the conversation is made clear and that teacher feel safe during the conversation (Lipton \& Wellman, 2007). This seems to suggest that when provided with a safe environment, teachers could reflectively discuss their practice with the coach and would be more open to change. This would also mean that coaching dismisses the idea of teacher working in isolation as it allows teachers to be more open in discussing their experiences with the coach in order to generate change in their practices.

\section{Trust}

The findings of the study showed that trust highly existed during coaching. Teacher values coach's input once trust is developed. Therefore, it is important that teachers trust the coach. It also creates a safe and comfortable environment when they communicate and most importantly coach maintains confidentiality of what is shared to them. Before teachers could share their problems with the coach, they need to establish trust towards the coach. Establishing trust can be done by valuing the teachers' experience and expertise and by assuring the teachers that conversations between coach and teachers would be confidential as suggested by Bean and Swan Dagen (2012). In terms of exercising the appropriate way to communicate, coach should practice facilitation, consultation as well as collaboration (Bean \& Swan Dagen, 2012).

In addition, coaches need to build trust among teachers and using effective communication as suggested by Bean and Swan Dagen (2012) would speed up the process. Once the roles and trust were established, the feedback given by the coach would be more than valuable to help teachers improve their practices. It also creates 


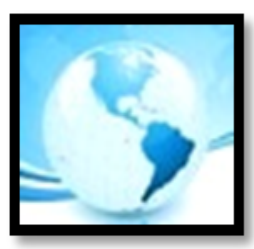

\section{MALAYSIAN ONLINE JOURNAL OF EDUCATIONAL MANAGEMENT (MOJEM)}

opportunities for teachers to reflect on their own practices and make necessary changes. It is only when the teachers are able to see the importance of creating change in the area of their choice that they would make the attempt to create such change and vice versa (Knight, 2007). This seems to suggest that by developing trust towards the coach, it enables the teacher to receive help and support from the coach to help them make decision regarding the change in instructional improvement.

\section{Feedback and Reflect}

The analysis of the study reveals that sub-constructs feedback and reflect were insignificant. This finding reflects that both sub-constructs is not highly practiced in coaching implementation in schools. The role of coach as a leader is not only in creating changes within the classroom but also in terms of school culture and climate (Davis, 2016; Matsumura \& Wang, 2010; Porche et al., 2012). In addition, the findings of the study suggest providing and receiving feedback as well as reflecting on one's on performance have yet to become part of the working culture in Malaysian schools. In comparison, a study done by Steckel (2009) had revealed that coaches, teachers and principals reported that there were observable changes in the overall school culture. They observed that teachers and coaches were able to conduct reflective dialogue openly. Nevertheless, there were some similarities in the findings with the previous study i.e. collaboration, problem solving and inquiry has also become part of teacher practices (Steckel, 2009). As such, the school culture can change new values and behaviour and replace the old ones, which already existed in the system (Elmore, 2004).

\section{Relationship between Coaching and Coach Leadership}

Coaching is a practice which focuses on improving teacher practices. It is linked to Fullan's work on educational improvement (Fullan, 2006). The core business of coaching is to change adult behaviour in the classroom. Although change in instructional practices would involve both bottom up and top down decision, it is up to teachers to decide on how and when the changes should take place. This can be made possible with the existence of appropriate resources. (Fullan, 2006; Cornett \& Knight, 2009). The analysis using SEM SmartPLS shows that there is a significant relationship between coaching constructs and coach leadership. The result of the analysis shows that collaboration has the most significant relationship with leadership followed by support and trust. Collaboration is most significant because coaching is about teachers working together with the coach in order to allow changes and improvements to take place (Jorissen, Salazar, Morrison, \& Foster, 2008; Regge \& Soine, 2008; Russo, 2004).

The findings also show that coaching is a form of support provided to teachers in helping them improve classroom practices as suggested by Knight (2011). It also allows collaboration between teachers and coach, which allow teachers to receive feedback and reflect on their practices. Coaching also allows them to establish trust towards the coach. Building trust may not be easy, but once it is established, it allows teachers to be more open to share their problems (Ertmer, 2005). Thus, as a leader, the coach has to play the right leadership role to gain teachers' trust. After all, it is the coach's responsibility to help create the change in the learning environment in school (Fullan, 2006; Elmore, 2004). On the other hand, the finding on sub constructs feedback and reflects reveals that there were no significant relationships between the two constructs and leadership. This is suggesting that constructs feedback and reflect were not highly being practiced during coaching. This highlights the importance to create more focus on both constructs when carrying out coaching. After all, coaching is about being able to reflect on one's practices with the help of feedback received.

Additionally, based on the findings of the study, there is a significant relationship between collaboration, support and trust. However, the effect of those three coaching sub-constructs were small. This means that, as leaders, coaches should play a greater role in coaching teachers. Their performance and commitment in providing support to teachers to improve practices would yield a greater effect towards instructional improvement. Therefore, having the right skills and knowledge would help coaches to lead better. 


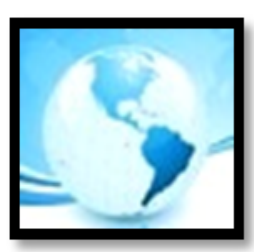

\section{MALAYSIAN ONLINE JOURNAL OF EDUCATIONAL MANAGEMENT (MOJEM)}

The findings of the study also illustrate the impact of coaching on leadership performance of the coach during coaching in the attempt to invoke changes related to instructional improvement. Being able to reflect on ones' own practices shows how teachers were accountable and committed towards making professional improvements. Coaches on the other hand were able to guide and provide appropriate feedback which help teachers to reflect better. Their collaboration in trying to solve problems related to teaching and learning is vital. This is because it will affect not only the learning outcomes, but also overall school improvements.

Nevertheless, dealing with adult learners namely teachers, is not an easy task. Moreover, creating change is even more difficult without proper support. Additionally, with poor implementation, coaching can turn out to be ineffective (Cornell \& Knight, 2009). Therefore, when coaching others, a leader needs to have the right knowledge, technical skills as well interpersonal skills as creating change involves various aspects (Glickman, 2007) regardless if they are directly or indirectly related to one another. In other words, as a leader, a coach needs to be knowledgeable and resourceful. In fact, it is vital that both coaches and teachers play the right roles of leadership during coaching to allow instructional improvements to take place.

\section{CONCLUSION}

Coaching focuses on changing teacher practices. The core business of coaching is in changing adult behaviour in the classroom. Although change in instructional improvement would involve bottom up or top down decision but it is up to teachers to decide on how and when the changes would take place. It is only when teachers are able to see the importance of creating change in the area of their choice that they would make the attempt to create such change and vice versa. By playing the right role of teacher leadership, it enables the teacher to make decision regarding the changes in instructional improvement.

Overall, the role of coaching is not only in creating changes within the classroom but also changes in school culture and climate. As such it would require improvements in practices such as collaboration, problem solving and inquiry learning to become part of classroom practices. In fact, changing school culture involves changing existing values and behaviour into new ones. Therefore, teachers should work together with coaches to help create the changes in the learning environment of the school. Additionally, playing the right role of leadership among teachers and coaches is very important to ensure the success in implementing changes within the classroom and the school as a whole.

\section{REFERENCES}

Balan, R. M., Manko, T. P., \& Phillips, K. F. (2011). Instructional improvement through professional development. Teaching and Learning Journal, 5(2), 1-19.

Barber, M., \& Mourshed, M. (2007). How the world's best-performing school systems come out on top. London: McKinsey and Company.

Bean, R. M., \& Swan Dagen, A. (2012). Best practices of literacy leaders. New York: Guilford Press.

Blase, J. \& Blase, J. (1999). Leadership for staff development: Supporting the lifelong study of teaching and learning. Athens, GA: University of Georgia, College of Education.ERIC Document Reproduction Service No. ED439123).

Brady, C. (2007). Coaches' voices bring 6 lessons to light. Journal of Staff Development, 28(1), 46-49.

Bright, N. (2011). Five habits of highly effective teachers: A role for administrators. The School Administrator, 68(9), 33-35. 


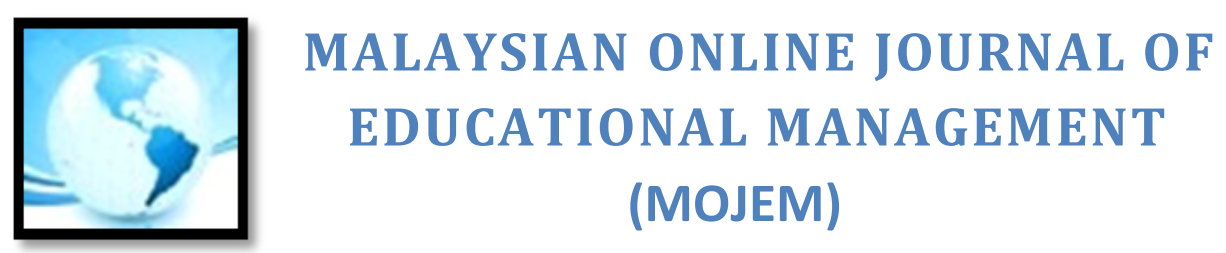

Brodie, K. (2014). Learning about learner errors in professional learning communities. Educational Studies in Mathematics, 85, 221e239. http://dx.doi.org/ 10.1007/s10649-013-9507-1.

Burns, N., \& Grove, S. K. (2009). The practice of nursing research (6th ed.). St. Louis: Elsevier.

Bush, R. N. (1984). Effective staff development. In making our schools more effective: Proceedings of three state conferences. San Francisco, CA: Far West Laboratories.

Bush, T. (2011). Theories of educational leadership and management (4th ed.). London: Sage Publications.

Caine, R. N., \& Caine, G. (2001). Overview of the systems principles of natural learning. Retrieved June 19, 2018, from: http://www.cainelearning.com/files/Principles_overview.pdf

Cassidy, J., Garrett, S., Maxfield, P., \& Patchett, C. (2009). Literacy coaching: Yesterday, today, and tomorrow. In J. Cassidy, S. D. Garrett, \& M. Sailors (Eds.), Literacy coaching: Research and practice: 2009 CEDER yearbook (pp. 15-27). Texas: Corpus Christi.

Chin, W. W. (1998). Commentary: Issues and opinion on Structural Equation Modelling. MIS Quarterly, 22(1), 7-16.

Cornett, J., \& Knight, J. (2009). Research on coaching. In J. Knight (Ed.), Coaching: Approaches \& perspectives (pp. 192-216). Thousand Oaks, US: Crowin.

Creswell, J. W. (2013). Research design: Qualitative, quantitative, and mixed methods approaches. Los Angeles, CA: Sage Publications.

Darling-Hammond, L., \& Rothman, R. (2011). Teacher and leader effectiveness in high-performing education systems. Washington, DC: Alliance for Excellent Education.

David, O. F. (2007). Teacher's questioning behavior and classroom instruction pattern. Humanity \& Social Sciences Journal, 2(2), 127-131.

Davis, S. L. (2016). Literacy coaching through teacher's lenses: A phenomenological study (Doctoral dissertation). Retrieved from https://eric.ed.gov/?id=ED570581

Eismin, D. H. (2015). The effectiveness of the literacy coaching model of professional development by teachers and literacy coaches (Unpublished doctoral dissertation). University of Cincinnati, Cincinnati.

Elmore, R. (2004). School reform from the inside out: Policy, practice, and performance. Cambridge, MA: Harvard Education Press.

Elsenberg, E. (2016). The path to progress: Instituting a culture of coaching this school year. Literacy Today, 34(1), 10-12.

Ertmer, P. A., Richardson, J., Cramer, J., Hanson, L., Huang, W., Lee, Y., et al. (2005). Professional development coaches: Perceptions of critical characteristics. Journal of School Leadership, 15(1), 52-75.

Feger, S., Woleck, K., \& Hickman, P. (2004). How to develop a coaching eye. Journal of Staff Development, 25(2), 14-18.

Frye, A. S., Robins, J., \& Ed, D. (2015). Teachers' perceptions of the literacy coach's impact on classroom practice (Unpublished doctoral dissertation) Baker University. 


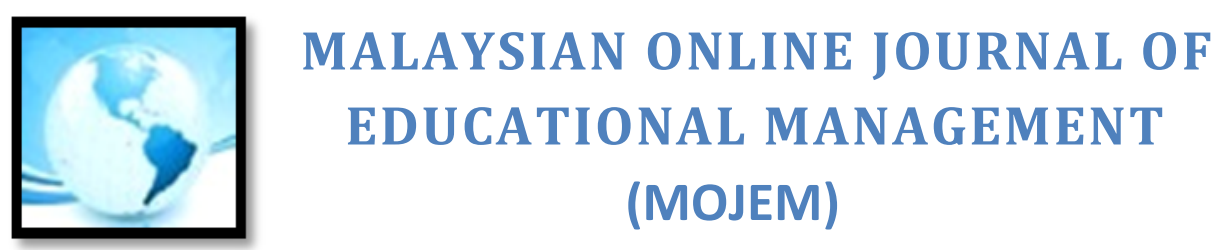

Fullan, M. (2006). Change theory as a force for school improvement. In J. M. Burger, C. F. Webber, \& P. Klinck (Eds.), Intelligent leadership. Studies in educational leadership (pp. 27-39). Dordrecht: Springer.

Glickman, C. D., Gordon, S. P., \& Ross-Gordon, M. (2007). Supervision and instructional leadership: A developmental approach (6th ed.). Boston: Pearson.

Glickman, C. D., Gordon, S. P., \& Ross-Gordon, J. M. (2005). The basic guide to superVision and instructional leadership. Boston, Mass: Pearson Education, Inc.

Goleman, D. (2002). The new leaders: Transforming the art of leadership into the Science. UK: Time Warner Books.

Guskey, T. R., \& Yoon, K. S. (2009). What works in professional development? Phi Delta Kappan, 19(7), 495-500. http://doi.org/10.2307/20446159

Hair, J. F. J., Hult, G. T. M., Ringle, C., \& Sarstedt, M. (2014). A primer on Partial Least Squares Structural Equation Modeling (PLS-SEM). USA: Sage Publications.

Hall, D. (2005). Moving from professional development to professional growth. Learning \& Leading with Technology, 32(5), 36-38.

Harris, A., \& Muijs, D. (2005) Improving schools through teacher leadership. Berkshire: Open University Press.

Hussain, H., Jais, J., \& Rahman, Z. A. (2000). Multimedia education software as effective learning tool for proficiency in English. Paper presented at the International Seminar on Education and Training in an IT Environment- ISET 2000, UNITAR, Petaling Jaya, Malaysia.

Ingersoll, R. M. (2007). Short on power, long on responsibility teacher quality: The teacher' s problem? Little input no say. Development, 65(1), 20-25.

Jones, M. G., Gardner, G. E., Robertson, L., \& Robert, S. (2013). Science professional learning communities: Beyond a singular view of teacher professional development. International Journal of Science Education, 35, 1756-1774. http://dx.doi.org/10.1080/09500693.2013.791957.

Jorissen, K., Salazar, P., Morrison, H., \& Foster, L. (2008, October). Instructional coaches: Lessons from the field. Principal Leadership, 9(2), 17-19.

Joyce, B., \& Showers, B. (1980). Improving in-service training: The messages of research. Educational Leadership, $37(5), 379-385$.

Joyce, B. R., \& Showers, B. (1996). The evolution of peer coaching. Educational Leadership, 53(6), 12-16.

Joyce, B. R., \& Showers, B. (1984) Power for staff development through research on training. Washington, D.C.: Association for Supervision and Curriculum Development.

Killion, J., Harrison, C., Colton, A., Bryan, C., Delehant, A., \& Cooke, D. (2016). A systemic approach to elevating teacher leadership. Retrieved from https://learningforward.org/docs/default-source/pdf/a-systemicapproach-to-elevating-teacher-leadership.pdf

Knight, J. (2004). Progress through partnership. Journal of Staff Development, 25(2), 32-37.

Knight, J. (2006). Instructional coaching. The School Administrator, 63(4), 36-40. 


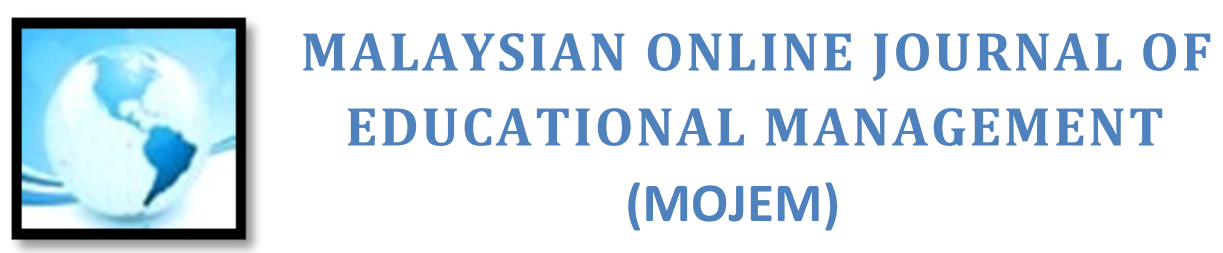

Knight, J. (2007). Instructional coaching: A partnership approach to improving instruction. Thousand Oaks, CA: Corwin Press.

Knight, J. (2011). Unmistakable impact: A partnership approach from dramatically improving instruction. Thousand Oaks, CA: Corwin.

Lim, C. S., Fatimah, S., \& Tan, S. K. (2002). Cultural influences in teaching and learning of mathematics: Methodological challenges and constraints. In D. Edge, \& B. H. Yeap (Eds.), Mathematics education for a knowledge-based era (pp. 138-149). Singapore: Association of Mathematics Educators.

Lipton, L., \& Wellman, B. (2007). How to talk so teachers will listen. Educational Leadership, 65(1), 30-34.

Little, J. W. (2003). Inside teacher community: Representations of classroom practice. Teachers College Record, 105(6),913-945.

Malm, B. (2009). Towards a new professionalism: Enhancing personal and professional development in teacher education. Journal of Education for Teaching, 35, 77-91. http://doi.org/10.1080/02607470802587160

Marsh, J. A., McCombs, J. S., \& Martorell, F. (2009). How instructional coaches support data-driven decisionmaking: Policy implementation and effects on Florida middle schools. Educational Policy, 24(6), 872-907.

Matsumura, L., \& Wang, E. (2014). Principals' sense making of coaching for ambitious reading instruction in a highstakes accountability policy environment. Education Policy Analysis Archives, 22(51), 1-37. doi:10.14507/epaa.v22n51.2014

McTighe, J., \& Brown, J. L. (2005). Differentiated instruction and educational standards: Is détente possible? Theory into Practice, 44(3), 234-244.

Ministry of Education (MOE). (2007). School division. Kuala Lumpur: Ministry of Education.

Ministry of Education (MOE). (2010). Memperkasa kepimpinan pengajaran di sekolah [Enhancing educational leadership in school. Kuala Lumpur: Ministry of Education.

Ministry of Education (MOE). (2013). Malaysian Education Blueprint. Kuala Lumpur: Ministry of Education.

Mohd Zawawi Ali. (2002). Persepsi guru terhadap penyeliaan pengajaran di sebuah sekolah menengah di daerah Pasir Putih, Kelantan. [Teachers perception towards supervision in a secondary school in Pasir Putih Kelantan] (Unpublished doctoral dissertation). Universiti of Malaya, Malaysia.

Nunally, J. C., \& Bernstein, I. H. (1994). Psychometric theory ( ${ }^{\text {rd }}$ ed.). New York: Mcgraw-Hill.

Parman, K. D. (2015). School reform and coaching: Identifying structures for successful implementation of a data informed decision-making program. (Doctoral dissertation). Retrieved from http://pdxscholar.library.pdx.edu/open_access_etds/2487/. Paper 2487.

Porche, M., Pallante, D., \& Snow, C. (2012). Professional development for reading achievement results from the Collaborative Language and Literacy Instruction Project (CLLIP). The Elementary School Journal, 112(4), 649-671.

Ramayah, T., Cheah, J., Chuah, F., Ting, H., \& Mumtaz, M. (2018). Partial Least Squares Structural Equation Modelling using SmartPLS 3.0. Kuala Lumpur: Pearson.

Reed, M. J. (2015). An explanatory mixed methods study of how classroom teachers perceive instructional coaching 


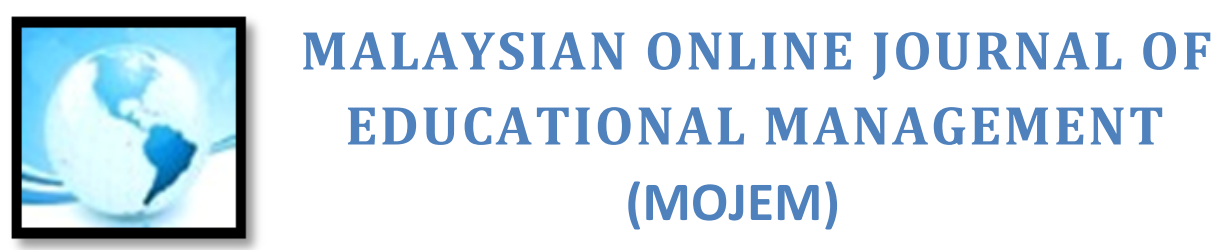

at an urban high school in Pennsylvania (Unpublished doctoral dissertation), Drexel University.

Regge, J., \& Soine, K. (2008). Renton school district: Professional development coaches. Washington State Kappan, 2(1), 26-37.

Richlin, L. (2001). Scholarly teaching and the scholarship of teaching. New Directions for Teaching and Learning, 86, 57-68.

Rosenholtz, S. (1989). Teacher's workplace: The social organization of schools. New York: Longman.

Russo, A. (2004). A school based coaching. Retrieved from http://hepg.org/helhome/issues/20_4/helarticle/school-based-coaching_269

Sharifah Maimunah, S. Z. (2000). Current trends and main concerns as regards to science curriculum development and implementation in selected states in Asia: Malaysia. In M. Poisson (Ed.), Science education for contemporary society: Problems, issues and dilemmas. Final report of the international workshop on the reform in the teaching of science and technology at primary and secondary level in Asia: Comparative references to Europe. Paper presented at the International Workshop on the Reform in the Teaching of Science and Technology at Primary and Secondary Level in Asia: Comparative References to Europe, Beijing, China, 27-31 March (pp. 39-45). Switzerland: International Bureau of Education

Sergiovanni, T. J., \& Starratt, R. J. (1979). SupervisionHuman Perspectives. New York: Mcgraw Hill Book.

Steckel, B. (2009). Fulfilling the promise of literacy coaches in urban schools: What does it take to make an impact? The Reading Teacher, 63(1), 14-23.

Sullivan, S., \& Glanz, J. (2000). Supervision that improves teaching: Strategies and techniques. California: Corwin Press Inc.

Tan, Y. P., \& Arshad, M. Y. (2014). Teacher and student questions: A case study in Malaysian secondary school. Problem-Based Learning Asian Social Science, 10(4), 174-182.

Thomas, E. E., Bell, D. L., Spelman, M., \& Briody, J. (2015). PreK-3rd grade teacher professional development experience, $44(2), 1-6$.

Thornburg, D., \& Mungai, A. (2011). Teacher empowerment and school reform. Journal of Ethnographic and Qualitative Research, 5(4), 205-217. Retrieved from http://web.ebscohost.com.ezp.waldenulibrary.org/ehost/pdfviewer/pdfviewer?vid=21 \&sid=cc3433232394-49b7-a383-47d52153a17c\%40sessionmgr113\&hid=112

Toll, C. (2009). Literacy coaching. In J. Knight (Hrsg), Coaching: Approaches and perspectives, (S.56-69) Thousand Oaks: Corwin Press.

Vangrieken, K., Meredith, C., Packer, T., \& Kyndt, E. (2017). Teacher communities as a context for professional development: A systematic review. Teaching and Teacher Education, 61, 47-59. http://doi.org/10.1016/j.tate.2016.10.001

Zepeda, S. J. (2007). The principal as instructional leader: A handbook for supervisors. (2nd ed.). Larchmont, NY: Eye on Education. 